\title{
MULTIPROXIES (BENTHIC FORAMINIFERA, OSTRACODS AND BIOPOLYMERS) APPROACH APPLIED TO IDENTIFY THE ENVIRONMENTAL PARTITIONING OF THE GUADIANA RIVER Estuary (Iberian Peninsula)
}

\author{
Lazaro Luiz Mattos Laut ${ }^{1 *}$, IARa Martins Moreira Matos Clemente ${ }^{2}$, Pierre Belart ${ }^{1}$, Maria Virgínia Alves

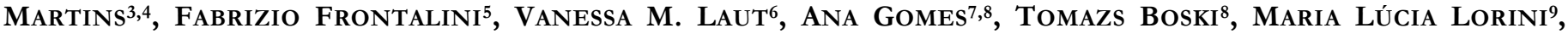 \\ RAFAEL R. ForTES ${ }^{9}$ AND MARIA ANTONIETA dA CONCEIÇÃo RodRIGUES ${ }^{3}$
}

1 Universidade Federal do Estado do Rio de Janeiro - UNIRIO, Laboratório de Micropaleontologia - LabMicro, Av. Pasteur, 458, Urca, Rio de Janeiro, Rio de Janeiro, Brazil, CEP. 22290-240. lazarolaut@hotmail.com, pberlart@gmail.com.

2 Programa de Pós-Graduação em Análises de Bacias e Faixas Móveis. Faculdade de Geologia, Universidade do Estado do Rio de Janeiro, Av. São Francisco Xavier, 524, sala 4037F, Maracanã, Rio de Janeiro, RJ, Brazil, CEP. 20550-013 - iarammmc@hotmail.com,

3 Universidade do Estado do Rio de Janeiro - UERJ, Faculdade de Geologia, Departamento de Estratigrafia e Paleontologia, Av. São Francisco Xavier, 524, Maracanã, sala 2020, 20550-013 Rio de Janeiro, RJ, Brazil - virginia.martins@ua.pt, tutucauerj@gmail.com.

4 Universidade de Aveiro, Departamento de Geociências, GeoBioTec, 3810-193 Aveiro, Portugal.

5 Dipartimento di Scienze Pure e Applicate (DiSPeA), Università degli Studi di Urbino "Carlo Bo", Campus Scientifico "E. Matt ei", Località Crocicchia,61029, Urbino, Italy, fabrizio.frontalini@uniurb.it

6 Universidade Federal Fluminense, Programa de Pós-graduação em Biologia Marinha e Ambientes Costeiros, Outeiro São João Batista, s/nº, Niterói - Rio de Janeiro, Brazil, CEP. 24001-970, vanessalaut@hotmail.com.

7 Centro Interdisciplinar de Arqueologia e Evolução do Comportamento Humano, Faculdade de Ciências Humanas e Sociais, Universidade do Algarve, Campus Universitário de Gambelas, Edifício 1,8005-139, Faro, Portugal aisgomes@ualg.pt.

8 Universidade do Algarve, Edifício 7, Campus Universitário de Gambelas, 8005-139, Faro, Portugal aisgomes@ualg.pt, tboski@gmail.com.

9 Universidade Federal do Estado do Rio de Janeiro - UNIRIO, Laboratório de Ecologia Bêntica, Av. Pasteur 458, s. 411, Urca, Rio de Janeiro, RJ, Brazil, CEP 22290-240, mluc.lorini@gmail.com, rafaelfortes@hotmail.com.

*CorResponding AUTHOR, lazarolaut@hotmail.com

Received on 01 Fabruary 2016

Received in revised form on 13 April 2016

Accepted on 15 April 2016

\section{Editor:}

Herminio Ismael de Araújo-Júnior, Universidade do Estado do Rio de Janeiro, Brazil
Citation:

Laut, L.L.M., Clemente, I.M.M.M., Belart, P., Martins, M.V.A., Frontalini, F., Laut, V.M., Gomes, A., Boski, T., Lorini, M.L., Fortes, R.R., Rodrigues, M.A.C., 2016. Multiproxies (benthic foraminifera, ostracods and biopolymers) approach applied to identify the environmental partitioning of the Guadiana River Estuary (Iberian Peninsula). Journal of Sedimentary Environments, 1(2): 178-195.

\begin{abstract}
The Guadiana River is the fourth longest river in Europe and is a natural frontier between southern Portugal and Spain. This river was historically used to transport minerals exploited in the region since the Roman Empire and therefore suffered human interventions that have been intensified after the industrial revolution. The Guadiana River has in its limits the Guadiana Valley Natural Park, which is of great value for the Conservation of Geobiodiversity. This study mainly aims to identify zones with the environmental characteristics in the estuarine area of the Guadiana River based on the distribution and ecology of microorganisms (ostracods and foraminifera) associated with physicochemical parameters and sedimentological and geochemical (carbohydrate, lipid, protein, total organic
\end{abstract}

carbon and total sulfur) data. Fifty-five foraminifera taxa were identified along the estuary with dominance of Ammonia tepida and Miliammina fusca and 13 ostracods taxa with dominance Leptocythere lacertosa and Loxoconcha elliptica. Detrended correspondence analysis (DCA) performed using biotic and abiotic variables indicated that $\mathrm{pH}$, grain size, total organic carbon (TOC) and lipids were the most influent factors in the distribution of these organisms. Four zones were identified in the Guadiana River estuary: i) Low estuary - region with the largest marine influence with sandy sediment, higher salinity and total sulfur and mainly represented by the dominance of estuarine species of foraminifera (Ammonia tepida and Cribroelphidium vadescens) and by the ostracods (Darwinula stevensoni, Semicytherura sulcata 
and Urocythereis oblonga); ii) Intermediate estuary - region characterized by neutral $\mathrm{pH}$ and sandy sediment enriched in carbohydrates; this region is characterized by the presence of the ostracods species Cytherois fischeri and Neocytherideis subulata and by calcareous and agglutinated species in foraminiferal assemblages; iii) Upper estuary - silt, high TOC, proteins and lipids content, and by the presence of Loxoconcha elliptica; iv) Freshwater environment - has similar characteristics to the upper estuary, but do not display foraminifera and was composed of ostracod species such as Cyclocypris ovum, Heterocypris incongruens and Ilyocypris sp. These species are commonly found in freshwater environments or in waters with very low salinity. The predetermined limit in previous studies for the intermediate/upper estuary shifted approximately $5 \mathrm{~km}$ further north. This effect may be due to human influence, since a dam was built on the river decreasing the freshwater flow and allowing marine water entrance to an inner area of the estuary.

Keywords: Microfossils. Bioindicators. Meso-tidal estuary. Estuarine hydrodinamic.

\section{Introduction}

Estuaries represent one of the most biologically productive natural habitat of the planet and offer countless ecosystem services that rely on the overall environmental quality (Costanza et al., 1997). The rapid world population growth particularly in coastal areas has resulted in a great ecological stress on aquatic ecosystems, like estuaries (Flemer and Champ, 2006). The effects on the local biota depend on the nature and the volume of the effluents, whether they are discharged directly into the estuary from a point source or, indirectly, through river system and, eventually, on the hydrographical and geomorphological properties of the estuary (Alve, 1995). Every estuarine ecosystem is unique and represents a complex buffer zone between fresh and salt water environments.

The Guadiana River crosses extensive rural area of massive sulphide deposits, the Iberian Pyrite Belt, with intense mining extraction since Roman Age (Palanques et al., 1995; Leistel et al., 1998). Despite the pyrite extraction has ceased in the last decade, the estuary is still affected by the input of domestic sewages from two cities located near the mouth (Chícharo et al., 2001; Domingues et al., 2005). Since 2002 , more than $80 \%$ of the freshwater flow has been regulated by the Alqueva Dam that is $140 \mathrm{~km}$ upstream of the estuarine mouth and minimizes the abrupt river discharges to the estuary. This dam has a water storage capacity of ca. $4150 \mathrm{hm}^{3}$ (Cravo et al., 2006). The impounding of freshwater behind dams causes a significant reduction in freshwater discharge in such areas (Humborg et al., 1997) that results in a decrease in suspended particulate matter and nutrient concentrations (Wetsteyn and Kromkamp, 1994; Humborg et al., 1997). This can lead to dramatic shifts in phytoplankton productivity and composition (Justic et al., 1995; Humborg et al., 1997), as nutrients play a key role in controlling primary production
(Libes, 1992; Mortimer et al., 1998; Cruzado et al., 2002). These changes originated marked effects on the biogeochemical cycling of nutrients, in the structure of the food web in coastal areas, and in turn affects biological productivity as well as the ecological balance of these ecosystems (Wright and Worrall, 2001; Cruzado et al., 2002).

The use of benthic organisms such as foraminifera and ostracods as proxies of environmental conditions (hydrodynamic and/or pollution) in coastal environments has been intensified in recent years (Souza et al., 2010). Benthic foraminifera are particularly useful for classifying estuaries (e.g., types of estuaries, salinity gradients, hydrodynamic conditions, sedimentological compartments) and to identify anthropic impacts (Nichols, 1974; Laut et al. 2010, 2011, 2012; Souza et al., 2010). Each estuary has its own characteristic assemblages that mirror specific environment parameters and conditions (Nichols, 1974).

Coimbra et al. (2007) indicated that ostracods can also be used as bioindicators in estuaries like foraminifera because they have high sensitivity to environmental changes and high potential for preservation in the sediment. However, the studies on ostracods fauna in coastal regions started only in 1960. According to Laut et al. (2014), the current knowledge of the distribution of foraminiferal and ostracod assemblages and their environmental constraints in estuarine regions can represent the starting point for monitoring and environmental management and serve as the background for studies of sea level changes and Quaternary evolution of coastal regions. Muñoz et al. (1995) used for the first time foraminiferal and ostracod assemblages to identify estuarine compartments by using only qualitative parameters in the Iberian Peninsula.

The aims of this study is to characterize the quality of organic matter, physicochemical parameters and benthic 
foraminiferal and ostracod assemblages distribution after Alqueva Dam construction using multivariate analyses to identify different environmental sectors of Guadiana River estuary.

\section{Study area}

The Guadiana River headland is located in Lagoas de Ruidera (Spain) at 1,700 m altitude. The river runs $810 \mathrm{~km}$ until reaching the Atlantic Ocean between the Portuguese town Vila Real de Santo António and Spanish town Ayamonte. The Portuguese stretch of the river is $260 \mathrm{~km}$ long, of which $110 \mathrm{~km}$ delimit the border with Spain (INAG, 2001; Chícharo et al., 2006). The Guadiana River estuary is located in SW Portugal and in physical terms embraces the $70 \mathrm{~km}$ of the total length of Guadiana River (Wolanski, 2006). Boski et al. (2008) sets the Guadiana Estuary as a rich wetland zone, where saltmarshes dominate and salt pans, lagoons, tidal creeks, intertidal flats, barrier islands and sandy spits are widespread. Many other habitats of high ecological value are also found in this region. The hydrologic regime of the Guadiana River reflects the regional Mediterranean climate that is characterized by dry and hot summers as well as mild and wet winters (Morales, 1993).

The Guadiana River estuary is a mesotidal system with semi-diurnal tides with a mean tidal range of $2 \mathrm{~m}$. The tidal wave along the coast moves from east to west, and produces slow velocity currents, when the flood is $0.40 \mathrm{~m} / \mathrm{s}$ to the west and ebb is $0.30 \mathrm{~m} / \mathrm{s}$ to the east during a mean spring tide (Instituto Hidrográfico, 1998). In the estuary, waves propagate following a synchronic model (floods can reach $0.80 \mathrm{~m} / \mathrm{s}$ and ebb can reach $0.90 \mathrm{~m} / \mathrm{s}$ during a mean spring tide) (Morales et al., 2006). The estuary is prolonged offshore by a submerged delta (Morales, 1997), where fluvial sediment is mixed with the marine material arriving from longshore sediment transport (Gonzalez et al., 2001). The Guadiana River discharge shows a marked inter-annual and seasonal variability (Morales et al., 1997). During periods of maximum discharge, tidal currents can rework and carry all of the sediments that are moved by the river to the sea (Morales et al., 1997).

\section{Material and methods}

\subsection{Sampling and sample preparation}

In September of 2010, ten sediment samples were collected in the subtidal zone of the Guadiana River estuary in the low tide period (Fig. 1). The sampling points were selected to identify estuarine gradients (Tab. 1).

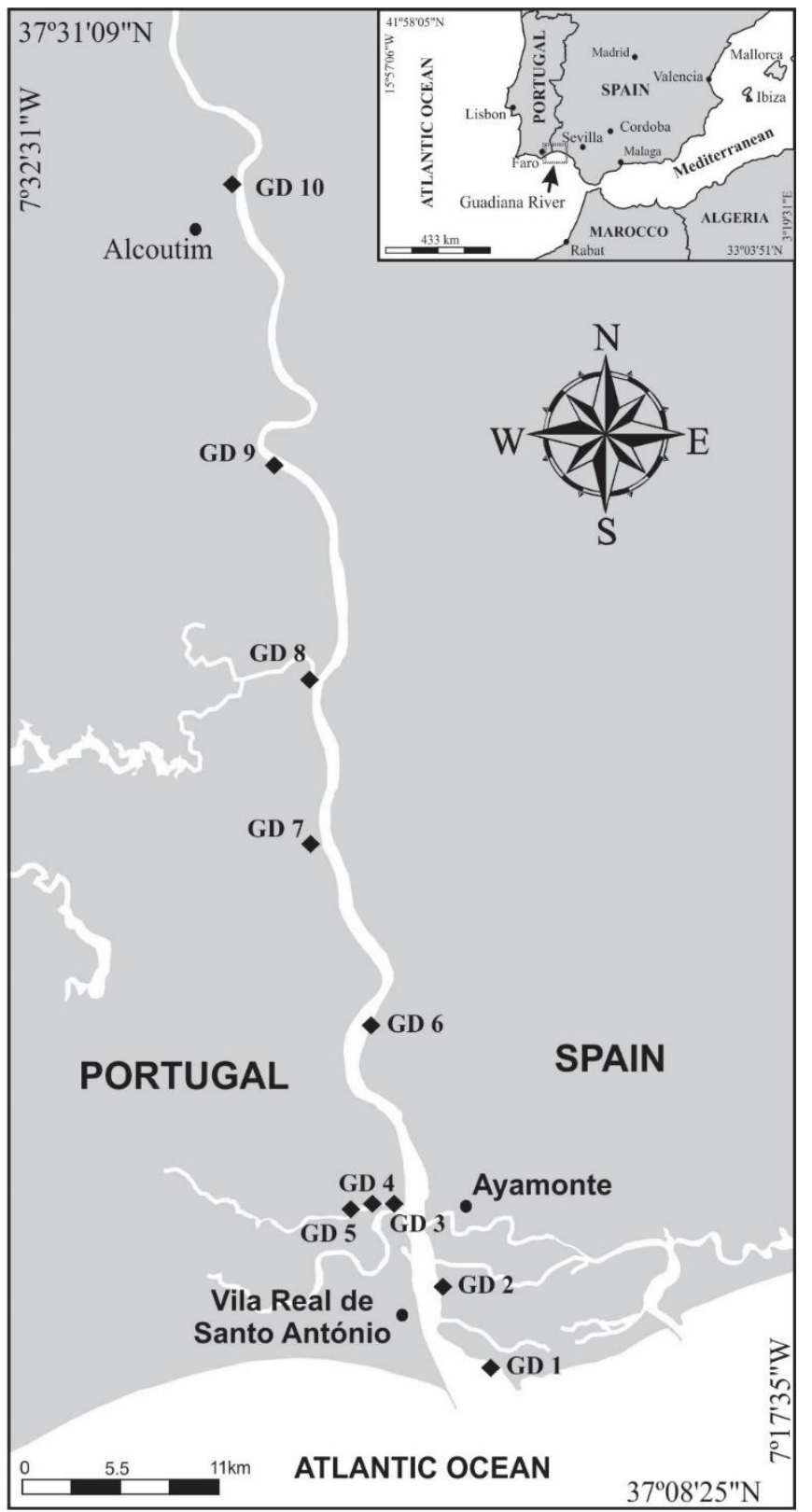

Fig. 1. Location of the studied stations along the Guadiana River estuary, Algarve, Portugal.

In each station, a total of $50 \mathrm{ml}$ of sediment were collected in triplicate using a van Veen Grab for foraminiferal and ostracod analyses (Fig. 1). The sediment was stored in plastic containers with alcohol $70 \%$ and Rose Bengal $\left(2 \mathrm{~g} \mathrm{~L}^{-1}\right)$ to avoid the tests degradation by bacterial activity and for the identification of living organisms during sampling. A total of $100 \mathrm{~g}$ of sediment in each station was sampled and stored in plastic bags to grain size and biopolymer analyses. 
The physiochemical parameters of the water, such as salinity (refractometer, model 10419, American Optical), temperature, $\mathrm{pH}$ ( $\mathrm{pH}$-meter CG837, Schott Gerate) and dissolved oxygen $\left(\mathrm{O}_{2}\right.$ Meter CG867, Schott Gerate) were measured in situ.

\subsection{Laboratory analyses}

\subsubsection{Grain size analysis}

Grain size analyses were accomplished according to the methodology described by Suguio (1973), by wet sieving separating mud (silt and clay) and sand fractions through a $0.062 \mathrm{~mm}$ sieve. The finest fractions were analyzed using the pipette method (Suguio, 1973).

\subsubsection{Geochemical analysis}

The percentages of total organic carbon (TOC) and total sulfur (S) were analyzed in dry sediment with a LECO SC 144 device, after acidification to remove carbonates, according to ASTM D 4239 (American Society for Testing and Materials - ASTM, 2008) and NCEA-C-1282 (United States Environmental Protection Agency-US EPA, 2002) methodologies. These analyses were performed in triplicate in Laboratório de Palifacies \& Fácies Orgânicas from Universidade Federal do Rio de Janeiro.

Biopolymers were determined according to Silva et al. (2013) and Martins et al. (2015a). The CHO, PTN and LIP concentrations were converted to carbon equivalents by using the following conversion factors: $0.49,0.40$ and 0.75 $\mu \mathrm{g} \mathrm{C} / \mathrm{g}$, respectively.

\subsubsection{Microfaunal analysis}

Benthic foraminiferal and ostracod assemblages were studied in the dry sediment fraction $63-1000 \mu \mathrm{m}$. In this study was considered only living (stained) foraminifera and ostracods. The foraminiferal and ostracod density, expressing as the number of stained tests (foraminifera) and carapace (ostracods) per volume (50 $\mathrm{ml}$ of sediment), was determined. Foraminiferal density (FD) is evaluated in number of test $/ 50 \mathrm{ml}$.

Foraminiferal genera were taxonomically classified in accordance with Loeblich and Tappan (1988). The taxonomic identification, at species level, was based on several publications, notably Todd and Brönnimann (1957), Boltovskoy et al. (1980), Debenay et al. (2002) and Martins and Gomes (2004). The ostracods were taxonomically classified in accordance with Yassini and Jones (1995) and Ruiz et al. (1997, 2000, 2005). The taxonomy has been checked in World Marine Species Database (Appendix 1) (Hayward et al., 2014).

Ecological indexes such as species richness (S), constancy $(c)$, diversity $(H)$, and equitability $(J)$ were used in the data interpretation. The $S$ is the number of species recognized in each sample. The $H^{\prime}$ is an index proposed by ShannonWeaver (1948), which is appropriate for random samples of a community of species or sub-community of interest, and it is estimated by: $H^{\prime}=\Sigma$ pi $\ln$ pi, where pi represents the portion of $i$ - species in the sample and $\ln$ is the natural (base e) logarithm. Equitability $(J)$ is related to the distribution of individuals among the species, being proportional to the $H^{\prime}$ and inversely proportional to the dominance. It compares the $H^{\prime}$ index with the distribution of the observed species, maximizing the diversity. This index is obtained through $J^{\prime}=H^{\prime} / \ln$ (S). The software MVSP 3.1 was used for calculation of $H^{\prime}$ and $J$ '.

\subsection{Statistical analysis}

Only samples with at least 100 foraminifera or ostracods specimens were considered for statistical analyses because they may provide reliable results concerning the species representativeness in the assemblage composition (Fatela and Taborda, 2002). The GD09 (less than 100 foraminifera) and GD10 stations (without foraminifera) were excluded from statistical analysis. The relative abundances of the foraminiferal and ostracod taxa were analyzed by detrended correspondence analysis (DCA) and used to show their relationship with grain size, salinity, $\mathrm{pH}$, TOC and biopolymers (CHO, LIP and PTN). All data were normalized with square root of 0.5 . The DCA analysis computed as relative Euclidean distance was performed with PCord 5.0 software.

\section{Results}

\subsection{Abiotic parameters}

Salinity showed a gradient ranging from 28.06 (GD01) close to the estuary mouth to 0.18 in the upper part of the estuary (GD 09 and GD10). The higher values were measured in the tributary channel (GD04: 29.35 and GD05: 23.43). The $\mathrm{pH}$ values ranged from 6.6 to 7.78 along the estuary (Tab. 1). 
The TOC values remained low throughout the river (Tab. $1)$, the highest value $(1.88 \%)$ was found in the innermost area of the river, near Alcoutim town (GD10) and the lowest $(0.52 \%)$ near the river mouth (GD01).

The concentration of biopolymers showed a similar pattern of increasing gradient (GD01 to GD10), where the lowest values were largely identified at river mouth whereas relatively higher values in the inner part of the estuary (Tab. 1). The LIP, PTN and CHO ranged from 4.42 to 16.29 $\mathrm{mg} / \mathrm{C} \mathrm{g}$, from 1.24 to $4.4 \mathrm{mg} / \mathrm{C} \mathrm{g}$ and from 1.31 to 3.39 $\mathrm{mg} / \mathrm{C} \mathrm{g}$, respectively. Sulfur concentrations varied from $0.04 \%$ in the inner portion (GD10) to $0.11 \%$ in the outermost stations (GD02 and GD03).

Tab. 1. Physicochemical parameters, sedimentological and geochemical data of the Guadiana River estuary (TOC - Total Organic Carbon, S - Sulphur, CHO - Carbohydrates, LIP - Lipids, PTN - Proteins).

\begin{tabular}{ccccccccccccc}
\hline Stations & $\begin{array}{c}\text { Lat } \\
\text { North }\end{array}$ & $\begin{array}{c}\text { Long } \\
\text { West }\end{array}$ & pH & salinity & $\begin{array}{c}\text { TOC } \\
(\%)\end{array}$ & $\begin{array}{c}\mathrm{S} \\
(\%)\end{array}$ & $\begin{array}{c}\text { CHO } \\
\left(\mathrm{mg} . \mathrm{g}^{-1}\right)\end{array}$ & $\begin{array}{c}\text { LIP } \\
\left(\mathrm{mg} . \mathrm{g}^{-1}\right)\end{array}$ & $\begin{array}{c}\text { PTN } \\
\left(\mathrm{mg} \cdot \mathrm{g}^{-1}\right)\end{array}$ & $\begin{array}{c}\text { Sand } \\
(\%)\end{array}$ & $\begin{array}{c}\text { Silt } \\
(\%)\end{array}$ & $\begin{array}{c}\text { Clay } \\
(\%)\end{array}$ \\
\hline GD01 & $37^{\circ} 11^{\prime} 41.0^{\prime \prime}$ & $07^{\circ} 24^{\prime} 21.5^{\prime \prime}$ & 7.38 & 28.06 & 0.52 & 0.07 & 1.31 & 4.42 & 1.24 & 100 & 0 & 0 \\
GD02 & $37^{\circ} 15^{\prime} 39.1^{\prime \prime}$ & $07^{\circ} 25^{\prime} 40.5^{\prime \prime}$ & 7.26 & 25.6 & 1.37 & 0.11 & 2.27 & 9.14 & 2.85 & 77 & 16 & 7 \\
GD03 & $37^{\circ} 18^{\prime} 29.5^{\prime \prime}$ & $07^{\circ} 26^{\prime} 35.7^{\prime \prime}$ & 6.9 & 11.85 & 1.36 & 0.11 & 2.28 & 10.59 & 1.92 & 48 & 24 & 28 \\
GD04 & $37^{\circ} 10^{\prime} 26.4^{\prime \prime}$ & $07^{\circ} 23^{\prime} 21.7^{\prime \prime}$ & 7.34 & 29.35 & 1.33 & 0.1 & 1.92 & 11.33 & 2.53 & 30 & 46 & 24 \\
GD05 & $37^{\circ} 12^{\prime} 53.5^{\prime \prime}$ & $07^{\circ} 25^{\prime} 55.9^{\prime \prime}$ & 6.89 & 23.43 & 1.54 & 0.1 & 2.54 & 15.61 & 3.27 & 10 & 66 & 24 \\
GD06 & $37^{\circ} 12^{\prime} 53.4^{\prime \prime}$ & $0^{\circ} 25^{\prime} 55.9^{\prime \prime}$ & 7.78 & 6.23 & 1.58 & 0.07 & 2.41 & 11.77 & 3.52 & 23 & 63 & 14 \\
GD07 & $37^{\circ} 12^{\prime} 53.2^{\prime \prime}$ & $07^{\circ} 25^{\prime} 55.9^{\prime \prime}$ & 7.16 & 2.09 & 1.87 & 0.08 & 3.39 & 15.81 & 3.88 & 32 & 56 & 12 \\
GD08 & $37^{\circ} 20^{\prime} 59.3^{\prime \prime}$ & $07^{\circ} 26^{\prime} 41.0^{\prime \prime}$ & 7.6 & 1.43 & 1.84 & 0.07 & 3.37 & 14.01 & 4.17 & 65 & 29 & 6 \\
GD09 & $37^{\circ} 24^{\prime} 14.7^{\prime \prime}$ & $07^{\circ} 27^{\prime} 31.8^{\prime \prime}$ & 6.76 & 0.18 & 1.88 & 0.06 & 3.30 & 14.00 & 4.25 & 36 & 10 & 54 \\
GD10 & $37^{\circ} 28^{\prime} 30.3^{\prime \prime}$ & $07^{\circ} 28^{\prime} 13.9^{\prime \prime}$ & 6.60 & 0.18 & 1.88 & 0.04 & 1.43 & 16.29 & 4.4 & 63 & 31 & 6 \\
\hline
\end{tabular}

Grain-size analysis indicated that the substrate at the stations in the mouth of the estuary was mostly composed of sand (GD01 - 100\% and GD02 - 74\%), with a marked reduction of the sandy fraction in the inner part of the estuary up to $10 \%$ at GD05). In the station GD09 the dominant textural fraction was the clay (54\%) (Tab. 1).

\subsection{Microfaunal parameters}

A total of 57 benthic foraminiferal taxa was identified along the Guadiana River estuary, 42 and 15 of which were calcareous and agglutinated, respectively (Appendix 1). Selected taxa are represented in Plates 1 and 2 . All the benthic foraminiferal data including FD, S, $H^{\prime}$ and $J$ ' are reported in Appendix 1. Foraminiferal density varied from zero (GD10) to 712 (GD01). The most abundant species were Ammonia tepida (mean of stations 28\%) followed by Miliammina fusca (mean of stations 34\%). Other calcareous species like Ammonia parkinsoniana, Cribroelphidium excavatum, Elphidium gunteri, Haynesina germanica, Miliolinella subrotunda, Quiqueloculina lamarckiana and Rosalina bradyi were constant in the samples but showed low values of relative abundance (Appendix 1).
The $H$ 'index was relatively lower in the GD01 and GD07 stations and the highest values (2.28) was recorded in the GD08 station. The $J$ ' showed values ranging from 0.4 (GD01) to 0.9 (GD09) (Appendix 1).

Along the Guadiana River estuary 13 ostracods taxa were found (Appendix 2; Plate 3). The density of living ostracods (number of specimens $/ 50 \mathrm{ml}$ sediment) ranged from 100 (GD05) to 1092 (GD02). The GD01 and GD10 stations with seven recognized taxa showed the highest $\mathrm{S}$. The $H^{\prime}$ index ranged from 0.33 (GD04) to 1.64 (GD01), the $J$ 'index showed the lowest value in GD04 (0.30) and the highest in GD03 (0.97). Loxoconcha elliptica (ranging from 14.3\%, in GD01, and 50.3\%, in GD06) and Leptocythere lacertosa (ranging from $4.3 \%$,in GD10, and $91.2 \%$, in GD04) were the most abundant ostracod species in the estuary (Appendix 2).

\subsection{Statistical analysis}

Multivariate DCA analysis was based on sediments granulometry, salinity, $\mathrm{pH}, \mathrm{TOC}$ and biopolymers (CHO, LIPs and PTN) and the relative abundance of the main 
foraminiferal and ostracods species. The axis 1 of the DCA explains $57 \%$ of data variability and the axis 2 only $6 \%$ (Fig. 2 ). Environmental variables with larger vectors and with lower angle with the axis 1 is $\mathrm{pH}$, grain size fractions (sand, silt and clay) and the percentage of TOC and LIP. For the axis 2 , the most important environmental variable was $\mathrm{CHO}$ content.

The DCA analysis distributed the species and stations into five groups. Group I is composed by the species of ostracods Darwinula stevensoni, Semicytherura sulcata and Urocythereis oblonga and by the station GD01. These variables responded positively mainly to $\mathrm{pH}$ and sand increasing and negatively to PTN, TOC and LIP.

Group II has not ostracods representatives but solely encloses benthic foraminifera, in particular Trochammina inflata as the only agglutinated foraminiferal taxon and the following calcareous species A. tepida, Ammonia sp., Astrononion stelligerum, Cribroelphidium excavatum, Cribroelphidium vadescens, Elphidium complanatum, Elphidium crispum, Elphidium gunteri and Patellina corrugata. These variables answered positively to the increasing of salinity. Group II also contains the stations GD02, GD03, GD04 and GD05.

Group III contains Cytherois fischeri and Neocytherideis subulata as ostracods taxa and the agglutinated species of foraminifera: Arenoparrella mexicana, Entzia macrescens, Miliammina fusca, Siphotrochammina lobata, Trochamminita salsa and Textularia earlandi. The following calcareous species also belong to this group: Adelosina longirostra, Ammonia parkinsoniana, Bolivina variabilis, Elphidium discoidale, Entzia polystoma, Haynesina germanica, Quinqueloculina lamarckiana, Quinqueloculina seminula and Rosalina bradyi. Group III also encompasses the stations GD06, GD07 and GD08 which seem to be positively associated with $\mathrm{pH}$, and $\mathrm{CHO}$ increase.

Group IV embraces the ostracod species L. elliptica and the station GD09 whereas Group V encompasses the species of ostracods Cyclocypris ovum, Heterocypris incongruens and Ilyocypris sp. as well as the station GD10. Both Groups IV and V had no foraminifera and responded positively to finer grained sediments, TOC and PTN and LIP content (biopolymers) and negatively to salinity, $\mathrm{pH}$ and sand fraction. The species of ostracod Leptocythere lacertosa is isolated in the DCA and seemed to positively respond to fine fraction increasing (Fig. 2).

\section{Discussion}

Most of the analyzed abiotic parameters showed gradients from the mouth to the inner area of the river. The sedimentary dynamic processes within this estuary are the result of the balance between discharges of freshwater and tides providing sediments that may be altered by climate, sea level fluctuations and human action (Camacho et al., 2014, 2015).

The studied stations are characterized by sand to very silty sand substrates. This distribution can be related to changes in the energy resulting from different tidal conditions and seasonal hydrodynamic (Dias et al., 2001). Grain-size analysis also indicated a gradient with coarser sediments at the mouth which became progressively finer towards inner zone of the estuary, though the sandy fraction is prevalent in the innermost stations (GD08 and GD10). This pattern of particle size distribution evidences the importance of marine hydrodynamic processes on the external part of the estuary (Machado et al., 2007).

Salinity decreased along the river. The stations GD01, GD02, GD03 and GD04, nearest the mouth, showed the highest values of salinity due to the proximity to the sea. The stations GD06-GD10 have lowest salinity, but also show the influence of the tides in the upper course. The hydrodynamic forces associated to a mesotidal regime, with an average range of $2 \mathrm{~m}$, and wave action that propagate into the interior of the Guadiana River estuary, lose progressively the energy (Morales, 1993; Muñoz et al., 1995). The action limit of the salt wedge in the estuary can be seen in the stations GD09 and GD10. The average values of the salinity found along the estuary were similar to those recorded by Muñoz et al. (1995) and Camacho et al. (2014, 2015). The station GD05 has a relatively high salinity despite being in the intermediate compartment of the river. This station is located in a tributary channel that receives a lower contribution of fresh water relative to the amount of saltwater and where the action of winds intensifies the evaporation. These processes increase salinity in this area (Morales, 1993; INAG, 2001). The $\mathrm{pH}$ values display low variability through the estuary suggesting minor change as also observed by Muñoz et al. (1995) and Camacho et al. (2014, 2015).

Values of TOC and biopolymers in the studied stations are relatively low and presents an opposite gradient to that of salinity. Values of TOC and biopolymers increase towards the river inland, probably due to an increase of continental organic matter contribution as noted by Cravo et al. (2006). According to Mendonça-Filho et al. (2003), when TOC concentrations exceed 4\%, the environment is dysoxic/anoxic. The higher values of TOC and biopolymers are observed in coastal environments with greater anthropic influence in tropical regions such as Guanabara Bay and Bertioga Channel (Brazil) and impacted regions at Iberian 
Peninsula such as in Ria de Aveiro (Mendonça-Filho et al., 2003; Eichler et al., 2003; Clemente et al., 2015; Martins et al., 2015a, b, c). Low TOC concentrations founded in Guadiana River Estuary were generally be observed in other coastal regions that are affected by wave action, such as in the Arade river in Portugal (Laut et al., 2015) and in the Paraiba do Sul River delta in Brazil (Laut et al., 2012). These results indicate that the hydrodynamic conditions in Guadiana River estuary avoids the deposition of organic matter and its preservation in surface sediments.
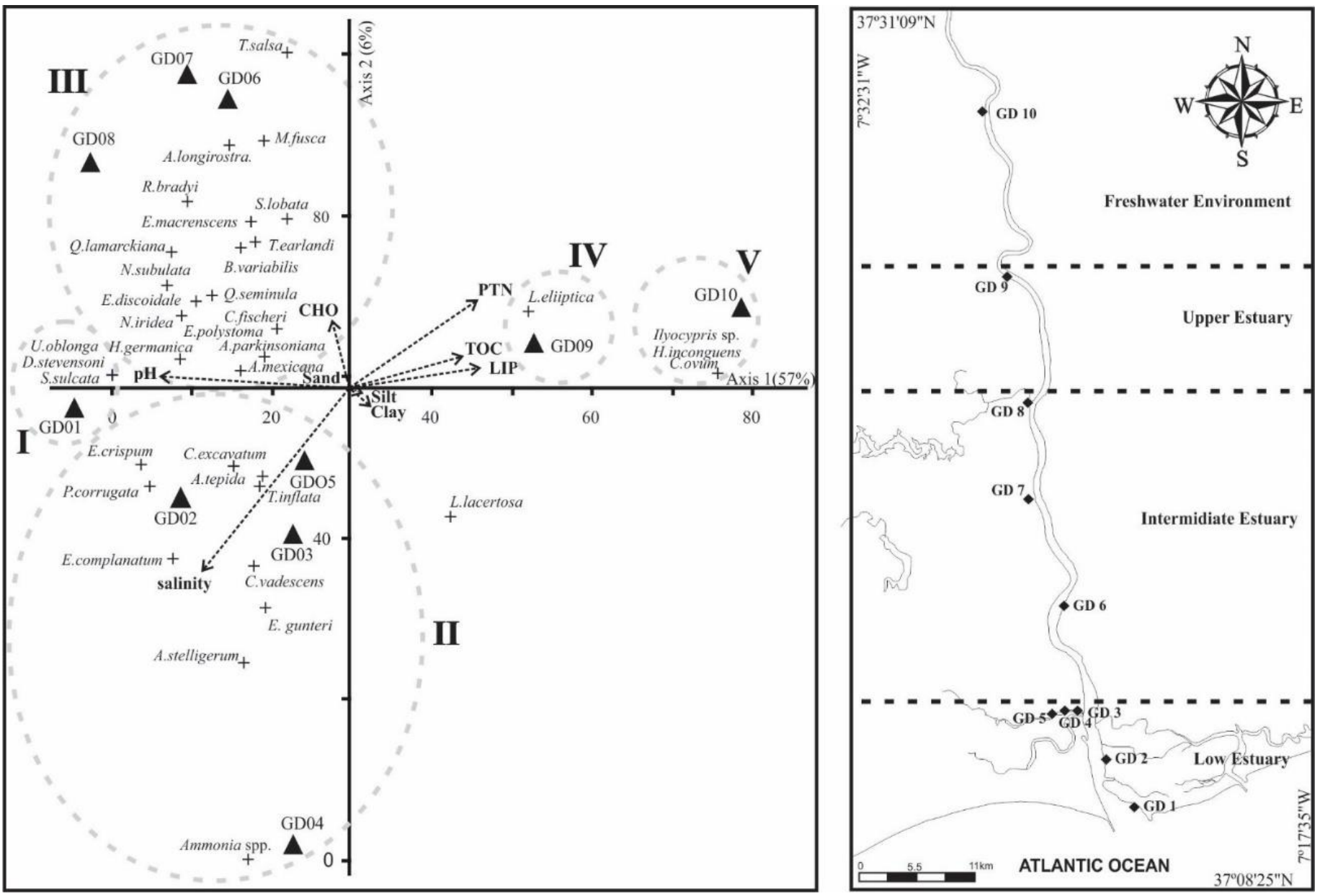

Fig. 2. DCA multivariate analysis of the stations and foraminiferal and ostracods species, the distribution of stations groups and estuarine compartments proposed to Guadiana River Estuary (PTN - proteins, CHO - carbohydrates; LIP - lipids; TOC - total organic carbon).

\subsection{Ecological parameters}

The studied stations of the Guadiana River estuary showed higher number of species of foraminifera (57 species) than those described by Muñoz et al. (1995). However, the specific richness was comparable to the values documented by Camacho et al. $(2014,2015)$. This value is higher than that found in other estuaries of the south of Iberian Peninsula such as that of Arade River (Laut et al., 2014) and Tinto-Odiel system (Ruiz et al., 2005). In the Guadiana River estuary, mostly cosmopolitan and calcareous species (42 species) were found such as $A$. tepida, $A$. parkinsoniana, C. excavatum, E. gunteri, H. germanica, M. subrotunda, Q. lamarckiana, Q. seminula and R. bradyi that are considered characteristic of mixohaline and brackish environments (Muñoz et al., 1995; Ruiz et al., 2005; Laut et al., 2014). Agglutinated species, such as A. mexicana, E. macrescens, E. polystoma, T. inflata and $M$. fusca, are relatively abundant in the studied stations.

They are cosmopolitan and occur in other Iberian Peninsula estuaries and lagoons, such as the Arade river (Laut et al., 2014) and Ria de Aveiro (Martins et al., 2010, 2013, 2014, 2015 a, c). These species have high tolerance to salinity variations and tend to live in brackish environments 
such as estuaries, mangroves and salt marshes (Souza et al., 2010).

The number of ostracod species recognized in the Guadiana River estuary are similar to those described by Muñoz et al. (1995) in this estuary and also in the River Arade estuary, also located in Algarve, Portugal (Laut et al., 2015). The most abundant taxa were Loxoconcha elliptica, Leptocythere lacertosa and Cytherois fischeri. These species are considered cosmopolitan, indigenous and are adapted to eurihaline conditions in the estuaries of the Iberian Peninsula (Muñoz et al., 1995; Laut et al., 2015). The density, specific richness and diversity of foraminifera and ostracoda reflect a similar pattern to that found in the same area in previous studies, such as Muñoz et al. (1995) and Camacho et al. (2014, 2015). These authors suggest that factors such as salinity, grain size and the input of organic matter are the main factors driving the pattern of distribution of these organisms. The same is suggested by the results of DCA analysis included in Figure 2.

\subsection{Ecological parameters}

The DCA analysis (Fig. 2) indicated that the foraminiferal and ostracod species respond, to some extent, to abiotic variables such as salinity, grain size and organic matter (TOC and biopolymers) suggesting an influence of hydrodynamic factors along the river. These variables allowed to distinguish four distinct regions.

Low Estuary. Region with the largest marine influence that presents coarser sediment and highest salinity. This part comprises the region of the mouth represented by the Group I of the DCA (GD01 station and the following species of ostracod D. stevensoni, S. sulcata, U. oblonga) and the Group II of the DCA (GD02, GD03, GD04 and GD05) (Fig. 2). The latter includes calcareous foraminifera species such as $A$. tepida, A. stelligerum, C. excavatum, C. vadescens, E. crispum, E. complanatum, E. gunteri, P. corrugata, and the agglutinated species $T$. inflata that have high tolerance to changes in physicochemical parameters (Murray, 1991). These species were also found by Mendes et al. (2004) on the nearby continental shelf. Of these species, the most common in worldwide estuaries is Ammonia tepida (Murray, 1991). This species occurs due to its high tolerance to environmental variations (Martins et al., 2010, 2013, 2014, 2015 a, c). The same was observed by Muñoz et al. (1995) and Camacho et al. $(2014,2015)$ in this estuary. The ostracod species $S$. sulcata and $U$. oblonga live in marine and coastal brackish water environments (Perçin-Paçal et al., 2015). These species have also been identified in previous studies in this region (Muñoz et al., 1995) and also at the mouth of Arade River (Laut et al., 2015).

Intermidiate Estuary. Transitional region with sandy sediments and enriched in carbohydrates. This region is represented by the Group III of DCA including stations GD06, GD07 and GD08, and ostracods Cytherois fischeri and Neocytherideis subulata (Fig. 2) that are reported as estuarine species and commonly found in this area of the Guadiana River estuary (Muñoz et al., 1995) and at the mouth of the Arade River (Laut et al., 2015). This group also contains the agglutinated foraminifera species $A$. mexicana, E. macrescens, M. fusca, S. lobata, T. earlandi and T. salsa. Calcareous taxa such as Adelosina longirostra, Ammonia parkinsoniana, Bolivina variabilis, Elphidium discoidale, Entria polystoma, Haynesina germanica, Quinqueloculina lamarckiana, Quinqueloculina seminula and Rosalina bradyi are also grouped in it. Carbohydrates enrichment suggests that the organic matter has phytoplanktonic or detrital origin (Cotano and Villate, 2006). The source areas of detrital organic materials are probably the salt marsh estuary margins. The species $A$. mexicana, E. polystoma, E. macrescens, S. lobata and T. salsa should be also linked with this contribution (Souza et al., 2010). The great predominance of $M$. fusca species in this group is related to an increase of fluvial influence (Debenay et al., 2003; Camacho et al., 2014, 2015; Laut et al., 2014). The miliolids such as Q. seminula have been found in several transitional ecossystems associated with sandy sediment and basic to neutral pH (Eichler et al., 2003; Martins et al., 2013, 2014, 2015 a, c; Laut et al., 2014).

The region defined as intermediate estuary agrees with the previously defined in the Guadiana River (Muñoz et al. 1995). However, the boundary between this compartment and the upper estuary differs in about $5 \mathrm{~km}$ further north to the limits set by Muñoz et al. (1995). This effect may be related to the construction of the Alqueva Dam that began operating in 2002, this is after the study performed by Muñoz et al. (1995) for the Guadiana River estuary. According to Gonzalez et al. (2001), after the construction of the Alqueva Dam the river flow volume was greatly reduced. The anthropic change and the dry and arid climatic conditions during the sampling period of this work, promoted the reduction of river flow which may have facilitated the saline wedge entrance by some kilometers further inland.

Upper Estuary. This region is the innermost area of the Guadiana River estuary (Fig. 2). This zone is characterized by finer sediments (silt and clay), relatively high TOC content as well as by proteins and lipids enrichment. Group 
IV of the DCA (Fig. 2) represents this zone, composed of station GD09 and the species of ostracoda L. elliptica. The occurrence of the species L. elliptica along the Guadiana River estuary was also observed by Muñoz et al. (1995). This species is considered an indicator of eurihaline confined environments with high organic matter content enriched in lipids (Loureiro et al., 2009; Laut et al., 2015). This region was considered the area limit of the upper estuary (Fig. 2). Living foraminifera, which are known to avoid or be absent in freshwater environments, were yet found in this area, however with low density $(<100$ specimens $/ 50 \mathrm{ml})$. Foraminifera of this station were not considered in the statistical treatment, however, the presence of these living organims suggests that the salt wedge also are affecting this region and are moving each more northward.

Freshwater region. A region with characteristics similar to the upper estuary but with greatest influence of freshwater (Fig. 2). Group V represents this region and is composed by the station GD10 and by the ostracod species C. ovum, $H$. incongruens and Ilyocypris sp. Living foraminifera were not found in the station GD10. The identified ostracods species are commonly found in freshwater environments or in environments with very low salinity values (Muñoz et al., 1995; Külköylüoglu, 2003). The species L. lacertosa is isolated in quadrant IV of the DCA (Fig. 2) and might be associated with the enrichment of organic matter in lipids and proteins. This species is commonly found in environments with high concentrations of organic matter (Loureiro et al., 2009) and was observed in most stations, but had higher density values in the stations GD04 and GD05, located in a tributary channel. In these stations, a large number of ostracods juveniles were observed, possibly because they are more sheltered areas that favor the reproduction of this mesohalin species (Meric et al., 2010).

\section{Conclusion}

The Guadiana River estuary from the mouth to the innermost portion displayed a decreasing gradient of physicochemical parameters (i.e., salinity, $\mathrm{pH}$ ) and an increasing one of biochemical factors (TOC and biopolymers). On the basis of these factors coupled with benthic foraminiferal and ostracod assemblages, the estuary can be divided into four main regions (low estuary, intermediate estuary, upper estuary and freshwater environment) similar to those identified in previous studies. This study evidences a displacement of approximately $5 \mathrm{~km}$ further north of the intermediate/upper estuary limit. This may be related to human influence due to the construction of the Alqueva Dam that contributed to the decrease, at least seasonally, the freshwater flow, which allowed a strong salt wedge penetration in the innermost area of this river.

The distribution of ostracod assemblages confirm the identification and the separation of different environments in the Guadiana River Estuary. The appearance/disappearance of the ostracod species Neocytherideis subulata, Semicytherura sulcata and Urocythereis oblonga at the downstream region and Cyclocypris ovum, Cypridopsis vidua, Heterocypris incongruens and Ilyocypris sp. agrees with the suggested compartmentalization of this estuary.

\section{Acknowledgments}

This research was supported by National Council of Technological and Scientific Development - CNPq (Universal 445830/2014-0) and Fundação de Amparo à Pesquisa do Estado do Rio de Janeiro FAPERJ (Biota E26/11.399/2012). We thank the Young Talent Program for Science - CAPES by Pierre Belart scholarship. The authors would like to thank to Prof. Dr. João Graciano de Mendonça Filho and Dr. Frederico Sobinho da Silva for geochemistry analysis in Laboratório de Palinofacies \& Fácies Orgânicas - UFRJ.

\section{References}

Alve, E., 1995. Benthic foraminiferal responses to estuarine pollution: a review. Journal of Foraminiferal Research 25(3), 190 203.

American Society for Testing and Materials (ASTM) (2008) Standard test methods for Sulfur in the analysis sample of coal and coke using high-temperature tube furnace combustion methods ASTMD 4239. Available in: http:/ / engineers.ihs.com/documents/abstract/NWETIBA.

Boltovskoy, E., Giussani, G., Watanabe, S., Wright, R., 1980. Atlas of benthic shelf foraminifera of the Southwest Atlantic. Dr. W. Junk b.v., Publishers, The Hague, 147 pp., pl. 36.

Boski, T., Camacho, S., Moura, D., Fletcher, W., Wilamowski, A., Veiga-Pires, C., Correia, V., Loureiro, C., Santana, P., 2008. Chronology of the sedimentary processes during the postglacial sea level rise in two estuaries of the Algarve coast, Southern Portugal. Estuarine, Coastal and Shelf Science 77, 230-244. doi:10.1016/j.ecss.2007.09.012

Camacho, S.G., Moura, D.M.J., Connor, S., Scott, D.B., Boski, T., 2015. Taxonomy, ecology and biogeographical trends of dominant benthic foraminifera species from an AtlanticMediterranean estuary (the Guadiana, southeast Portugal). Palaeontologia Electronica 18.1.17A, 1-27.

Camacho, S., Moura, D., Connor, S., Boski, T., Gomes, A., 2014. Geochemical characteristics of sediments along the margins of an Atlantic-Mediterranean estuary (the Guadiana, Southeast Portugal): spatial and seasonal variations. Journal of Integrated Coastal Zone Management 14, 129-148. DOI: 10.5894/rgci452 Chícharo, M.A., Chícharo, L., Galvão, H., Barbosa, A., Marques, H., Andrade, J.P., Esteves, E., Miguel, C., Gouveia, C., 2001. 
Status of the Guadiana estuary (South Portugal) during 19961998: an ecohydrological approach. Aquatic Ecosystem Health and Management 4, 73-90. doi:10.1080/146349801753569298

Chícharo, L., Chícharo, M.A., Ben-Hamadou, R., 2006. Use of a hydrotechnical infrastructure (Alqueva Dam) to regulate planktonic assemblages in the Guadiana estuary: basis for sustainable water and ecosystem services management. Estuarine Coastal and Shelf Science 70, 3-18. doi:10.1016/j.ecss.2006.05.039

Clemente, I.M.M.M., Silva, F.S., Laut, L.L.M., Frontalini, F., Costa, V.C., Rodrigues, M.A.C., Pereira, E., Bergamaschi, S., Mendonça Filho, J.G., Martins, M.V.A., 2015. Bottom Sector Environments in Guanabara Bay (Rio de Janeiro, Brazil). Journal of Coastal Research 31(5), 1190-1204. doi.org/10.2112/JCOASTRES-D14-00104.1

Coimbra, J.C., Carreño, A.L., Geraque, E.A., Eichler, B.B., 2007. Ostracodes (Crustacea) from Cananéia-Iguape estuarine/lagoon system and geographical distribution of the mixohaline assemblages in southern and southeastern Brazil. Iheringia, Série Zoologia 97, 273 - 279. doi.org/10.1590/S007347212007000300010

Costanza, R., D'arge, R., Groot, R., Farber, S., Grasso, M., Hannon, M., 1997. The value of the world's ecosystem services and natural capital. Nature 387, 253-260.

Cotano, U., Villate, F., 2006. Anthropogenic influence on the organic fraction of sediments in two contrasting estuaries: A Biochemical approach. Marine Pollution Bulletin 52, 404-414. doi:10.1016/j.marpolbul.2005.09.027

Cravo, A., Madureira, M., Felícia, H., Rita, F., Bebianno, M.J., 2006. Impact of outflow from the Guadiana River on the distribution of suspended particulate matter and nutrients in the adjacent coastal zone. Estuarine, Coastal and Shelf Science 70, 63-75. doi:10.1016/j.ecss.2006.05.034

Cruzado, A., Velásquez, Z., Pérez, M.C., Bahamón, N., Grimaldo, N.S., Ridolfi, F., 2002. Nutrient fluxes from the Ebro River and subsequent across-shelf dispersion. Continental Shelf Research 22, 349-360. doi:10.1016/S0278-4343(01)00060-7

Debenay, J.P., Carbonel, P., Morzadec-Kerfourn, M.T., Cabauzon, A., Denèfle, M., Lézine, A.M. 2003. Multi-bioindicator study of a small estuary in Vendée (France). Estuarine, Coastal and Shelf Science 58, 843-860. doi:10.1016/S0272-7714(03)00189-6

Debenay, J. P.; Guiral., D., Parra, M., 2002. Ecological factors acting on the microfauna in mangrove swamps. The case of foraminiferal assemblages in French Guiana. Estuarine and Costal Shelf Science 55(4), 509-533. doi:10.1006/ecss.2001.0906

Dias, J.A., Ferreira, Ó. (Coord.), 2001. Projecto EMERGE Estudo multidisciplinar do estuário do Rio Guadiana. Relatório final 3/01. CIACOMAR, Universidade do Algarve, Olhão, Portugal. Available at http://w3.ualg.pt/ jdias/JAD/ebooks/ EMERGE/EMERGE_total_red.pdf.

Domingues, R.B., Barbosa, A., Galvão, H., 2005. Nutrients, light and phytoplankton succession in a temperate estuary (the Guadiana, south-western Iberia). Estuarine, Coastal and Shelf Science 64, 249-260. doi:10.1016/j.ecss.2005.02.017

Eichler, P.P.B., Eichler, B.B., Miranda L.B., Pereira, E.R.M., Kfouri, P.B.P., Pimenta, F.M., Bérgamo, A.L., Vilela, C.G., 2003.
Benthic foraminiferal response to variations in temperature, salinity, dissolved oxygen and organic carbon, in the Guanabara Bay, Rio de Janeiro, Brazil. Anuário do Instituto de Geociências 26, 36-51.

Fatela, F., Taborda, R., 2002. Confidence limits of species proportions in microfossil assemblages. Marine Micropaleontology 45(2), 169-174. doi:10.1016/S03778398(02)00021-X

Flemer, D.A., Champ, M.A., 2006. What is the future fate of estuaries given nutrient over-enrichment, freshwater diversion and low flows? Marine Pollution Bulletin 52, 247-258. doi:10.1016/j.marpolbul.2005.11.027

Gonzalez, R., Dias, J.M.A., Ferreira, O., 2001. Recent rapid evolution of the Guadiana Estuary (Southern Portugal/Spain). Journal of Coastal research SI34, 516-527.

Hayward, B.W., Cedhagen, T., Kaminski, M., Gross, O., 2014. World Modern Foraminifera database. Accessed through: World Register of Marine Species at www.marinespecies.org/ Consulted in 2015.

Humborg, C., Ittekot, V., Cosiascu, A., Bodungen, B.V., 1997. Effect of Danube River dam on Black Sea biogeochemistry and ecosystem structure. Nature 386, 385-388.

INAG, Instituto da Água, 2001. Plano de Bacia Hidrográfica do Rio Guadiana - Relatório Final. Partes I, II e III, 367p., Ministério do Ambiente e do Ordenamento do Território, Instituto da Água, Lisboa, Portugal.

Instituto Hidrográfico, 1998. Tidal Charts 1999, Volume I. Lisboa, Portugal.

Justic, D., Rabalais, N.N., Turner, R.E., Dortch, Q., 1995. Changes in nutrient structure of river-dominated coastal waters: stoichiometric nutrient balance and its consequences. Estuarine Coastal Shelf Science 40, 339-346. doi:10.1016/S02727714(05)80014-9

Külköylüoglu, O., 2003. Ecology of freshwater ostracoda (crustacea) from Lakes and Reservoirs in Bolu, Turkey. Jounal of Freshwater Ecology 18, 3.

Laut, L.L.M., Rodrigues, M.A.C., Silva, F.S., Mentzingen L.G., Martins, V., Boski, T., Gomes, A.I., Dias, J.M.A., Fontana, L.F., Clemente, I.M.M.M., Mendonca-Filho, J.G., Rapnã, L.C., 2015. Ostracods from Arade River Estuary, Algarve - Portugal. Anuário do Instituto de Geociências (UFRJ) 38, 115-126. doi.org/10.11137/2015_2_115_126

Laut, L.L.M., Cabral., I. A., Rodrigues, M.A.C., Silva, F.S., Martins, V., Boski, T., Gomes, A.I., Dias, J.M.A., Fontana, L.F., Laut, V.M., Mendonça-Filho, J.G., 2014. Compartimentos Ambientais do Estuário do Rio Arade, Sul de Portugal., com Base na Distribuição e Ecologia de Foraminíferos. Anuário do Instituto de Geociências (UFRJ) 37, 60-74. dx.doi.org/10.11137/2014_2_60_74

Laut, L.L.M., Silva, F.S., Figueiredo Jr, A.G., Laut, V.M., 2012. Assembleias de foraminíferos e tecamebas associadas a análises sedimentológicas e microbiológicas no delta do rio Paraíba do Sul, Rio de Janeiro. Pesquisas em Geociências 38, 251-268.

Laut, L.L.M., Laut, V.M., Silva, F.S., Figueiredo Jr, A.G., 2011. Modern Diatom Distributions in Guanabara Bay Sediment and Oceanic Areas, Rio de Janeiro (Brazil). Anuário do Instituto de Geociências 34, 72-95. 
Laut, L.L M., Ferreira, D.E.S., Santos, V.F., Figueiredo Jr, A.G., Carvalho, M.A., Silveira, O.F.M., 2010. Foraminifera, thecamoebians and palynomorphs as hydrodynamic indicators in Araguari Estuary, Amazon Coast, Amapá State - Brazil. Anuário do Instituto de Geociências 33, 52-65.

Leistel, J.M., Marcoux, E., Thiéblemont, D., Quesada, C., Sánchez, A., Almodóvar, G.R., Pascual., E., Sáez, R., 1998. The volcanichosted massive sulphide deposits of the Iberian Pyrite Belt. Mineralium Deposita 33, 2-30.

Libes, S., 1992. An introduction to marine biogeochemistry. John Wiley and Sons.

Loeblich, A.R. Jr., Tappan, H. 1988. Foraminiferal Genera and Their Classification. Van Nostrand Reinhold Campany, New York.

Loureiro, I.M., Cabral., M.C., Fatela, F., 2009. Marine Influence in Ostracods Assemblages of the Mira River Estuary: Comparison between Lower and Mid Estuary Tidal Marsh Transects. Journal of Coastal Research 56, 1356-1369.

Machado, A., Rocha, F., Gomes, C., Dias, J., 2007. Distribution and composition of suspended particulate matter in Guadiana estuary (southwestern Iberian Peninsula). Journal of Coastal Research SI50, 1040-1045.

Martins, V.A., Silva, F., Lazaro, L.M.L., Frontalini, F., Clemente, I.M., Miranda, P., Figueira, R., Sousa, S.H.M., Dias, J.M.A., 2015a. Response of benthic foraminifera to organic matter quantity and quality and bioavailable concentrations of metals in Aveiro Lagoon (Portugal). PLoS ONE 10 (2): e0118077. doi:10.1371/journal.pone.0118077

Martins, M.V.A., Mane, M.A., Frontalini, F., Santos, J.F., Silva, F.S., Terroso, D., Miranda, P, Figueira, R., Laut, L.L.M., Bernardes, C., Filho, J.G.M., Coccioni, R., Rocha, F., 2015b. Early diagenesis and adsorption by clay minerals important factors driving metal pollution in sediments. Environmental Science and Pollution Research 22, 10019-10033. doi: 10.1007/s11356-015-4185-4.

Martins, V.A., Laut, L.L.M., Silva, F.S., Miranda, P., MendonçaFilho, J.G., Fernández-Fernández, S., Sousa, S.S., Rodrigues, M.A.C., Rodrigues, A.R., Yamashita, C., Faria, E.O., Oliveira, R.R., Nagai, R.H., 2015c. Associações de foraminíferos em resposta a variações ambientais da Laguna de Aveiro - Portugal. Anuário de Geociências - UFRJ 38, 56-69. doi.org/10.11137/2015_2_56_69

Martins, MVA, Frontalini, F., Rodrigues, M.A.C., Dias, J.A., Laut, L.L.M., Silva, F.S., Clemente, I.M.M.M., Reno, R., Moreno, J., Sousa, S., Zaaboub, N., El Bour, M., Rocha, F., 2014. Foraminiferal Biotopes and their Distribution Control in Ria de Aveiro (Portugal): a multiproxy approach. Environmental Monitoring and Assessment 186, 8875-8897. doi: 10.1007/s10661-014-4052-7

Martins, M.V.A., Frontalini, F., Tramonte, K.M., Figueira, R.C.L., Miranda, P., Sequeira, C., Fernández-Fernández, S., Dias, J.A., Yamashita, C., Laut, L.M., Silva, F.S., Rodrigues, M.A.C., Bernardes, C., Nagai, R., Sousa, S.M., Mahiques, M., Rubio, B., Bernabeu, A., Rey, D., Rocha, F., 2013. Assessment of the health quality of Ria de Aveiro (Portugal): heavy metals and benthic foraminifera. Marine Pollution Bulletin 70, 18-33. doi.org/10.1016/j.marpolbul.2013.02.003.

Martins, V., Ferreira da Silva, E., Sequeira, C., Rocha, F., Duarte, A.C., 2010. Evaluation of the ecological effects of heavy metals on the assemblages of benthic foraminifera of the canals of Aveiro (Portugal). Estuarine, Coastal and Shelf Science 87, 293304. doi:10.1016/j.ecss.2010.01.011.

Martins, V., Gomes, V., 2004. Foraminíferos da Margem Continental NW Ibérica: Sistemática, Ecologia. Gomes, C. (Ed.), Aveiro, Portugal., 377 pp.

Mendes, I., Gonzalez, R., Dias, J.M.A., Lobo, F., Martins, V., 2004. Factors influencing recent benthic foraminifera distribution on the Guadiana shelf (Southwestern Iberia). Marine Micropaleontology 51, 171-192. doi:10.1016/j.marmicro.2003.11.001

Mendonça Filho, J.G., Menezes, T.R., Oliveira, E.A.E, Iemma, M.B., 2003. Caracterização da Contaminação por Petróleo e seus Derivados na Baía de Guanabara: Aplicação de Técnicas Organogeoquímicas e Organopetrográficas. Anuário do Instituto de Geociências - UFRJ 26, 69-78.

Meric, E., Avsar, N., Nazik, A., Barut, I.F., Bergin, F., Balkis, N., Oncel, M.S., Kapan-Yesilyurt, S. 2010. The response of benthic foraminifer, ostracod and mollusc assemblages to environmental conditions: a case study from the Camalti Saltpan (Izmir-Western Turkey). Mediterranean Marine Science 11, 05-32.

Morales, J.A., Delgado, I., Gutierrez-Mas, J.M., 2006. Sedimentary characterization of bed types along the Guadiana estuary (SW Europe) before the construction of the Alqueva dam. Estuarine, Coastal and Shelf Science 70, 117-131. doi:10.1016/j.ecss.2006.05.049

Morales, J.A., 1997. Evolution and facies architecture of the mesotidal Guadiana River delta (S.W. Spain Portugal). Marine Geology 138, 127-148. doi:10.1016/S0025-3227(97)00009-1

Morales, J.A., Ruiz, F., Jiménez, I., 1997. Papel de la sedimentación estuarina en el intercambio sedimentario entre el continente y el litoral: el estuário del Río Guadiana (España - Portugal). Revista de la Sociedad Geológica de España 10, 118-135.

Morales, J.A., 1993. Sedimentologia del Estuario de Rio Guadiana (S.W. España, Portugal). Ph.D. Thesis, University of Sevilla, Sevilla, Serv. Publ. Univ. Huelva, 274 pp.

Mortimer, R.J.G., Krom, M.D., Hall, P.O.J., Hulth, S., Stahl, H., 1998. Use of gel probes for the determination of high resolution solute distributions in marine and estuarine pore waters. Marine Chemistry 63, 119-129. doi:10.1016/S0304-4203(98)00055-3

Muñoz, F.R., Montero, M.L.G.R., González, J.A.M., 1995. Distribución y ecología de los foraminíferos y ostracodos actuales del estuário mesomareal del Río Guadiana (SO España). Geobios 29, 513-528.

Murray, J.W., 1991. Ecology and palaeoecology of benthic foraminifera. London, Longman Scientific and Technical., 397 p. Nichols, M.N. 1974. Development of the turbidity maximum in Rappahannock estuary, Summary. Memories du Institute de Geologie du Bassin d'Aquitaine 7, 19-25.

Palanques, A., Kenyon, N., Alonso, B., Limonov, A., 1995. Erosional and depositional patterns in the Valencia Channel 
mouth: an example of a modern channerl-lobe transition zone. Marine Geophysical Research 17, 503-517.

Perçin-Paçal., F., Altinsaçli, S., Balkis, H., 2015. An updated checklist of recent marine and coastal brackish water ostracods (Crustacea Ostracoda) in Turkey. Journal of Entomology and Zoology Studies 3 (3), 20-33.

Ruiz, F., González-Regalado, M.L., Pendón, J.G., Abad, M., Olías, M., Muñoz, J.M., 2005. Correlation between foraminifera and sedimentary environments in recent estuaries of Southwestern Spain: Applications to Holocene reconstructions. Quaternary International 140-141, 21-36. doi:10.1016/j.quaint.2005.05.002

Ruiz, F., González-Regalado, M.L., Baceta, J.I., Muñoz, J.M., 2000. Comparative ecological analysis of the ostracod faunas from low and high-polluted southwestern Spanish estuaries: a multivariate approach. Marine Micropaleontology 40, 345-376. doi:10.1016/S0377-8398(00)00048-7

Ruiz, F., González-Regalado, M.L., Morales, J.A., 1997. Ecología de ostrácodos en medios estuarinos: el Subsistema Carreras (rio Guadiana, SO de España). Estudios Geológicos 53, 249-262.

Silva, F.S., Laut, L.L.M., Carvalhal-Gomes, S.B.V., Fontana, L.F., Martins, M.V.A., Gomes, A.I., Clemente, I.M.M.M., Laut, V.M., Souza, R.C.C.L., Crapez, M.A.C., Rodrigues, M.A.C., MendonçaFilho, J. G., 2013. Caracterização geoquímica de sedimentos estuarinos do sul da Península Ibérica como ferramenta para o diagnóstico ambiental. In: Rodrigues, M.A.C., Pereira, S.D., Bergamachi, S. (Org.). Interação Homem-Meio nas zonas costeiras: Brasil/Portugal. 1. ${ }^{a}$ ed. Rio de Janeiro: Corbã Editora Artes Gráficas Ltda, p. 85-99.

Souza, V.M., Laut, L. L. M., Silva, F.S., Figueiredo Jr, A. G., Vital., H., Frazão, E., 2010. Foraminíferos Bentônicos e Atividade
Bacteriana como Ferramenta para Análise Ambiental no Estuário do Rio Pontegi, Rio Grande do Norte, Brasil. Anuário do Instituto de Geociências (UFRJ) 33, 20-30.

Suguio, K., 1973. Introdução à Sedimentologia. Edgard Blucher, São Paulo, 317p.

Todd, R., Brönnimann, P., 1957. Recent Foraminifera and thecamoebina from the Eastern Gulf of Paria: Cushman Foundation for Foraminiferal Research, Special Publication 3, 1 43.

United States Environmental Protection Agency (U.S. EPA), 2002. Methods for 2002. Methods for the determination of total organic carbon (TOC) in soils and sediments. Ecological Risk Assessment Support Center. NCEA-C-1282 Las Vegas: Office of Research and Development.

Wetsteyn, L.P.M.J., Kromkamp, J.C., 1994. Turbidity, nutrients and phytoplankton primary production in the Oosterschelde (The Netherlands) before, during and after a large-scale coastal engineering project (1980-1990). Hydrobiologia 282, 61-78.

Wolanski, E., Chícharo, L., Chícharo, M.A., Morais, P., 2006. An ecohydrology model of the Guadiana estuary (South Portugal). Estuarine Coastal and Shelf Science 70, 132-143. doi:10.1016/j.ecss.2006.05.029

Wright, J., Worrall, F., 2001. The effects of river flow on water quality in estuarine impoundments. Physics and Chemistry of the Earth 26, 741-746. doi:10.1016/S14641909(01)00079-X

Yassini, I., Jones, B.G., 1995. Foraminiferida and ostracoda from estuarine and shelf environments on the southeastern coast of Australia. Wollong, N. S. W (Ed.), The University os Wollongong Press, Australia, 484 pp. 
Appendix 1. Foraminiferal density (FD: number of test $/ 50 \mathrm{ml}$ ), species richness (S: number of species per sample), diversity ( $H^{\prime}$ ), Equitability $(J)$ and percentage of species in the studied stations of the Guadiana River estuary.

\begin{tabular}{|c|c|c|c|c|c|c|c|c|c|}
\hline Variables/Stations & GD01 & GD02 & GD03 & GD04 & GD05 & GD06 & GD07 & GD08 & GD09 \\
\hline Living foraminifera density (number of test/50 ml) & 712 & 304 & 207 & 248 & 300 & 199 & 252 & 141 & 27 \\
\hline Specific Richness (number of species per sample) & 27 & 25 & 10 & 10 & 9 & 19 & 15 & 21 & 8 \\
\hline Diversity $\left(H^{\prime}\right)$ & 1.12 & 2.16 & 1.28 & 1.25 & 1.32 & 1.42 & 1.06 & 2.26 & 1.78 \\
\hline Equitability $(J)$ & 0.4 & 0.7 & 0.6 & 0.5 & 0.6 & 0.5 & 0.4 & 0.7 & 0.9 \\
\hline Adelosina cliarensis (Heron-Allen \& Earland, 1930) & 0.1 & - & - & - & - & - & - & - & - \\
\hline Ammonia parkinsoniana (d'Orbigny, 1839) & 0.1 & 1.3 & - & 53.2 & 2.0 & 3.0 & - & 2.8 & - \\
\hline Ammonia sp. & - & 2.0 & - & 1.6 & - & - & - & - & - \\
\hline Ammonia tepida (Cushman, 1926) & 2.8 & 31.6 & 58.9 & - & 61.7 & 21.1 & 16.7 & 17.7 & 14.8 \\
\hline Asterigerinata mamilla (Williamson, 1858) & 0.7 & - & - & 0.8 & - & - & - & - & - \\
\hline Astrononion stelligerum (d'Orbigny, 1839) & 0.6 & 7.9 & 16.9 & 3.2 & - & - & - & 2.1 & - \\
\hline Aubignyna planidorso (Atkinson, 1989) & - & - & - & - & - & - & - & 0.7 & - \\
\hline Bolivina sp. & - & - & - & - & - & - & - & 0.7 & - \\
\hline Bolivina variabilis (Williamson, 1858) & - & 1.6 & - & - & - & 2.0 & - & 0.7 & - \\
\hline Cribroelphidium excavatum (Terquem, 1875) & - & 2.0 & - & - & 2.0 & - & - & 0.7 & - \\
\hline Cribroelphidium vadescens Cushman \& Brönniman, 1948 & - & 21.1 & 2.4 & - & 4.0 & 0.5 & 0.8 & - & 25.9 \\
\hline Discorbis parkeri Natland, 1950 & - & - & - & - & - & - & - & 0.7 & - \\
\hline Eggerelloides scaber (Williamson, 1858) & - & 0.7 & - & - & - & - & - & - & - \\
\hline Eilohedra vitrea (Parker, 1953) & 0.1 & - & - & - & - & - & - & - & - \\
\hline Elphidium complanatum (d'Orbigny, 1839) & 0.3 & 0.7 & - & - & - & - & - & - & - \\
\hline Elpbidium crispum (Linnaeus, 1758) & 2.1 & 0.3 & - & - & - & - & - & - & - \\
\hline Elphidium discoidale (d'Orbigny, 1839) & 1.7 & 0.5 & - & - & - & - & 0.4 & 6.4 & - \\
\hline Elphidium gerthi Van Voorthuysen, 1957 & - & 1.0 & - & - & - & - & - & - & - \\
\hline Elphidium gunteri Cole, 1931 & - & 1.3 & 13.0 & 0.4 & 3.3 & 0.5 & 1.6 & 7.1 & 18.5 \\
\hline Entria macrescens (Brady, 1870) & - & 0.3 & 0.5 & - & - & 1.0 & 0.8 & 1.4 & 3.7 \\
\hline Entria polystoma (Bartenstein \& Brand, 1938) & - & - & 5.3 & 29.8 & 1.3 & 2.0 & 0.4 & 2.1 & - \\
\hline Eoeponidella pulchella (Parker, 1952) & - & 0.3 & - & 0.4 & - & - & - & - & - \\
\hline Haynesina germanica (Ehrenberg, 1840) & 78.1 & 5.3 & - & - & 7.3 & - & 2.4 & 8.5 & 3.7 \\
\hline Hoeglundina elegans (d'Orbigny, 1878) & 1.0 & - & - & 0.8 & - & - & - & - & - \\
\hline Lamarckina haliotidea (Heron-Allen \& Earland, 1911) & 0.4 & - & - & - & - & - & - & - & - \\
\hline Lenticulina limbosa (Reuss, 1863) & - & - & - & - & - & - & - & 0.7 & - \\
\hline $\begin{array}{l}\text { Lepidodeuterammina eddystonensis Brönnimann \& Whittaker, } \\
1990\end{array}$ & - & - & - & - & - & - & - & 0.7 & - \\
\hline Lepidodeuterammina ochracea (Williamson, 1858) & - & - & - & - & - & 0.5 & - & - & - \\
\hline Lobatula lobatula (Walker \& Jacob, 1798) & 2.0 & - & - & - & - & - & - & - & - \\
\hline
\end{tabular}


Appendix 1 (cont.). Foraminiferal density (FD: number of test $/ 50 \mathrm{ml}$ ), species richness (S: number of species per sample), diversity $\left(H^{\prime}\right)$, Equitability $\left(J^{\prime}\right)$ and percentage of species in the studied stations of the Guadiana River estuary.

\begin{tabular}{|c|c|c|c|c|c|c|c|c|c|}
\hline Variables/Stations & GD01 & GD02 & GD03 & GD04 & GD05 & GD06 & GD07 & GD08 & GD09 \\
\hline Melonis sp. & - & 0.1 & - & - & - & - & - & - & - \\
\hline Miliammina fusca (Brady, 1870) & - & - & 0.5 & - & 16.0 & 60.3 & 71.0 & 34.0 & 25.9 \\
\hline Miliolinella sp. & 0.1 & - & - & 8.5 & - & - & - & - & - \\
\hline Miliolinella subrotunda (Montagu, 1803) & - & - & - & - & - & 0.5 & - & - & - \\
\hline Nonionella iridea Heron-Allen \& Earland, 1932 & 0.1 & 0.7 & - & 1.2 & - & - & - & 1.4 & - \\
\hline Patellina corrugata Williamson, 1858 & 1.0 & 0.3 & - & - & - & - & - & - & - \\
\hline Planorbulina mediterranensis d'Orbigny, 1826 & 0.1 & - & - & - & - & - & - & - & - \\
\hline Quinqueloculina lamarckiana d'Orbigny, 1839 & 2.1 & - & - & - & - & 0.5 & - & - & - \\
\hline Quinqueloculina poeyana d'Orbigny, 1839 & 0.1 & & & & & & & & \\
\hline Quinqueloculina spp. & 0.3 & - & - & - & - & 2.5 & - & 2.8 & - \\
\hline Reophax nana Rhumbler, 1913 & - & 0.1 & - & - & - & - & - & - & - \\
\hline Rosalina bradyi (Cushman, 1915) & 0.6 & - & - & - & - & - & 0.4 & - & - \\
\hline Siphotrochammina lobata Saunders, 1957 & - & - & 0.5 & - & - & 0.5 & 0.4 & - & - \\
\hline Sphaeroidina bulloides d'Orbigny, 1826 & 0.1 & - & - & - & - & - & - & - & - \\
\hline Textularia earlandi Parker, 1952 & - & 1.0 & - & - & - & 0.5 & 0.4 & - & - \\
\hline Textularia pseudogramen Chapman \& Parr, 1937 & 0.6 & - & - & - & - & - & - & - & - \\
\hline Tiphotrocha comprimata (Cushman \& Brönnimann, 1948) & - & - & - & - & - & - & - & 1.6 & - \\
\hline Tritaxis squamata (Jones \& Parker, 1860) & - & - & - & - & - & 0.5 & - & - & - \\
\hline Trochamminita salsa (Cushman \& Brönnimann, 1948) & - & - & - & - & - & 1.5 & 0.4 & - & - \\
\hline Wiesnerella auriculata (Egger, 1893) & 0.7 & - & - & - & - & - & - & - & - \\
\hline
\end{tabular}


Appendix 2. Ostracods density (number of test/50 ml), species richness (S: number of species per sample), diversity ( $\left.H^{\prime}\right)$, Equitability $(J)$ and percentage of species in the studied stations of the Guadiana River estuary.

\begin{tabular}{|c|c|c|c|c|c|c|c|c|c|c|}
\hline Variables/Stations & GD01 & GD02 & GD03 & GD04 & GD05 & GD06 & GD07 & GD08 & GD09 & GD10 \\
\hline Number of living organisms $(50 \mathrm{ml})$ & 1020 & 1092 & 549 & 103 & 100 & 141 & 210 & 954 & 948 & 927 \\
\hline Species Richness (S) & 7 & 5 & 3 & 3 & 3 & 4 & 3 & 3 & 3 & 7 \\
\hline Diversity $\left(H^{\prime}\right)$ & 1.64 & 1.07 & 1.06 & 0.33 & 0,99 & 0.83 & 0.84 & 0.70 & 0.84 & 1.55 \\
\hline Equitability $\left(J^{\prime}\right)$ & 0.84 & 0.66 & 0.97 & 0.30 & 0.90 & 0.63 & 0.76 & 0.64 & 0.77 & 0.80 \\
\hline Cyclocypris ovum (Jurine, 1820) & - & - & - & - & - & - & - & - & - & 12.8 \\
\hline Cypridopsis vidua (O.F. Muller, 1776) & - & - & - & - & - & - & - & - & - & 2.1 \\
\hline $\begin{array}{l}\text { Cytherois fischeri (Sars, 1866) Brady \& } \\
\text { Norman, } 1889\end{array}$ & - & 50.9 & 28.2 & 1.3 & 18.0 & 4.9 & 27.9 & 71.0 & 31.0 & - \\
\hline $\begin{array}{l}\text { Darwinula stevensoni (Brady \& Robertson, } \\
1870 \text { ) }\end{array}$ & 5.7 & - & - & - & - & - & - & - & - & 2.1 \\
\hline Heterocypris incongruens (Ramdohr, 1808) & - & - & - & - & - & - & - & - & - & 40.4 \\
\hline Ilyocypris sp. & - & - & - & - & - & - & - & - & - & 23.4 \\
\hline Leptocythere lacertosa (Hirschmann, 1912) & 8.6 & 27.6 & 26.9 & 91.2 & 55.1 & 44.5 & 7.7 & - & 6.9 & 4.3 \\
\hline $\begin{array}{l}\text { Loculicytheretta pavonia (Brady, 1866) Ruggieri, } \\
1954\end{array}$ & 2.9 & - & - & - & - & - & - & - & - & - \\
\hline Loxoconcha elliptica Brady, 1868 & 14.3 & 20.6 & 45.0 & 7.5 & 26.9 & 50.3 & 64.5 & 25.8 & 62.1 & 14.9 \\
\hline $\begin{array}{l}\text { Neocytherideis subulata (Brady, 1868) Wagner, } \\
1957\end{array}$ & 7.1 & 0.6 & - & - & - & 0.3 & - & 3.2 & - & - \\
\hline $\begin{array}{l}\text { Palmoconcha guttata (Norman, 1865) Penney, } \\
1987\end{array}$ & - & 0.3 & - & - & - & - & - & - & - & - \\
\hline $\begin{array}{l}\text { Semicytherura sulcata (Mueller, 1894) Ruggieri, } \\
1959\end{array}$ & 21.4 & - & - & - & - & - & - & - & - & - \\
\hline $\begin{array}{l}\text { Urocythereis oblonga (Brady, 1866) Wagner, } \\
1957\end{array}$ & 40 & - & - & - & - & - & - & - & - & - \\
\hline
\end{tabular}


Plate 1. A - Miliammina fusca (GD05); B - Arenoparrella mexicana (GD03); C - Siphotrochammina lobata (GD03); D - Tiphotrocha comprimata (GD08); E - Trochammina inflata (GD05); F - Adelosina cliarensis (GD01); G - Quinqueloculina seminula (GD05); H - Quinqueloculina poeyana (GD01); I - Quinqueloculina lamarckiana (GD01); J - Lobatula lobatula (GD01); K - Rosalina bradyi (GD01); L - Planorbulina mediterranensis (GD01); M - Asterigerinata mamilla (GD01); N - Asterigerinata mamilla (GD01); O - Astrononion stelligerum (GD03); P - Haynesina germanica (GD02).

\section{PLATE 1}

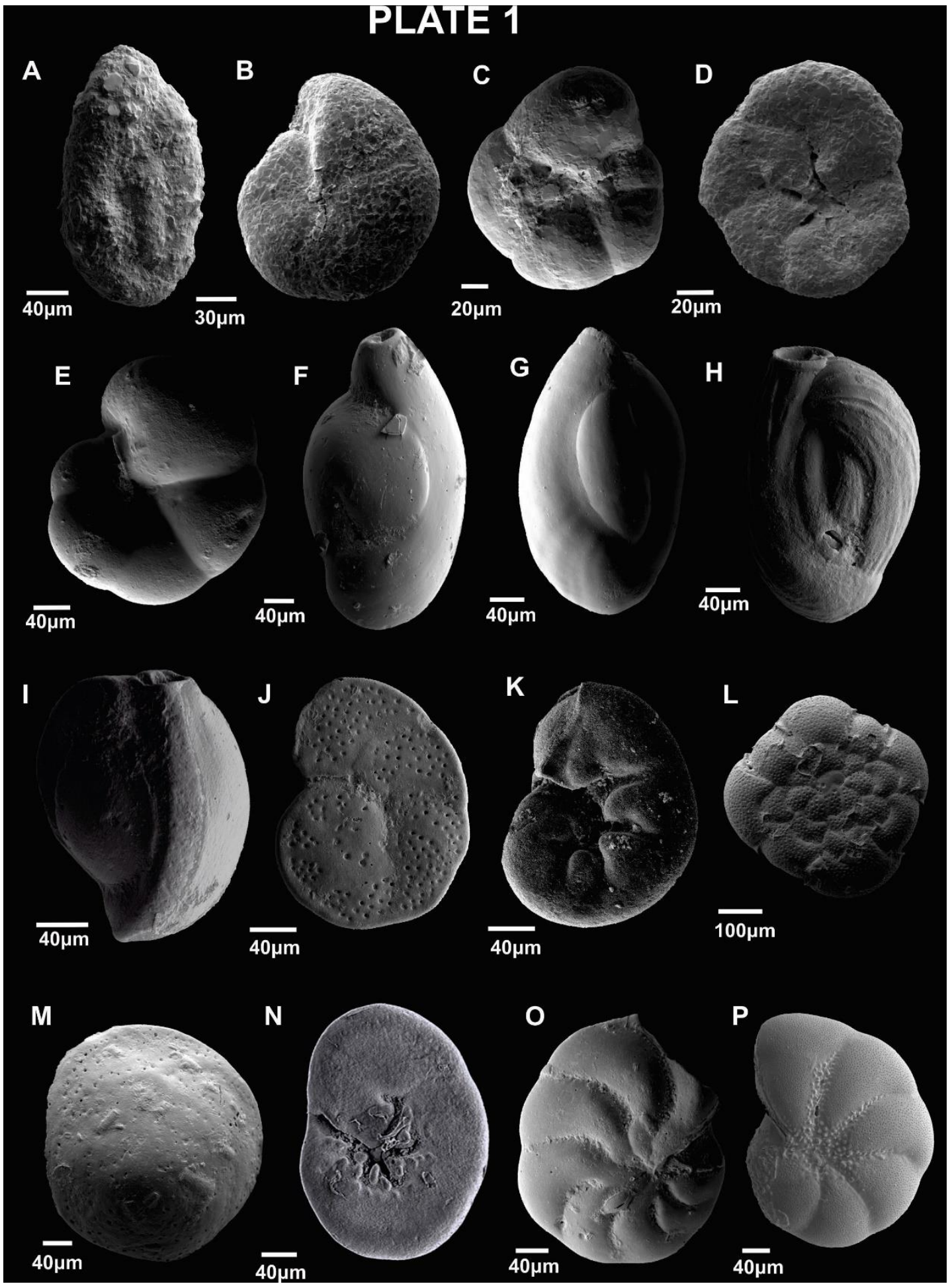


Plate 2. A - Bolivina variabilis (GD08); B - Elphidium gerthi (GD02); C - Elphidium complanatum (GD01); D - Elphidium crispum (GD01); E Elphidium gunteri (GD04); F - Elphidium excavatum (GD05); G - Ammonia tepida (GD02); H - A. tepida (GD02); I - Ammonia parkinsoniana (GD05); J - A. parkinsoniana (GD05); K - Entria polystoma (GD05).

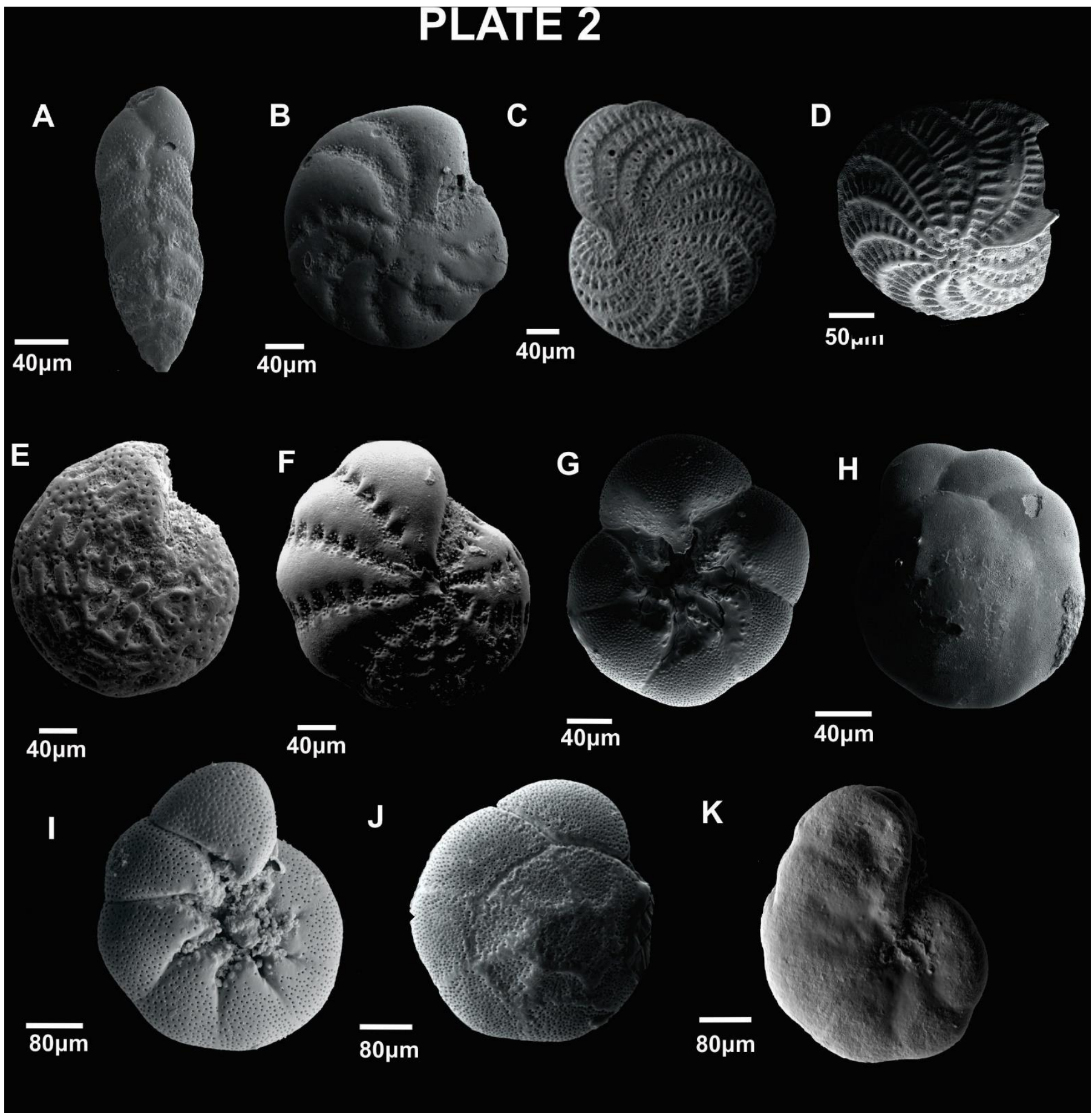


Plate 3. A - Loxoconcha elliptica (GD01); B - Cytherois fischeri (GD02); C - Leptocythere lacertosa (GD02); D - Palmoconcha guttata (GD02); E Neocytherideis subulata (GD01); F - Semicytherura sulcata (GD01); G - Urocythereis oblonga (GD01); H - Darwinula stevensoni (GD01); I Loculicytheretta pavonia (GD01); J - Heterocypris incongruens (GD10); K - Cypridopsis vidua (GD10L); L - Cyclocypris ovum (GD10); M - Ilyocypris sp. (GD10).

\section{PLATE 3}
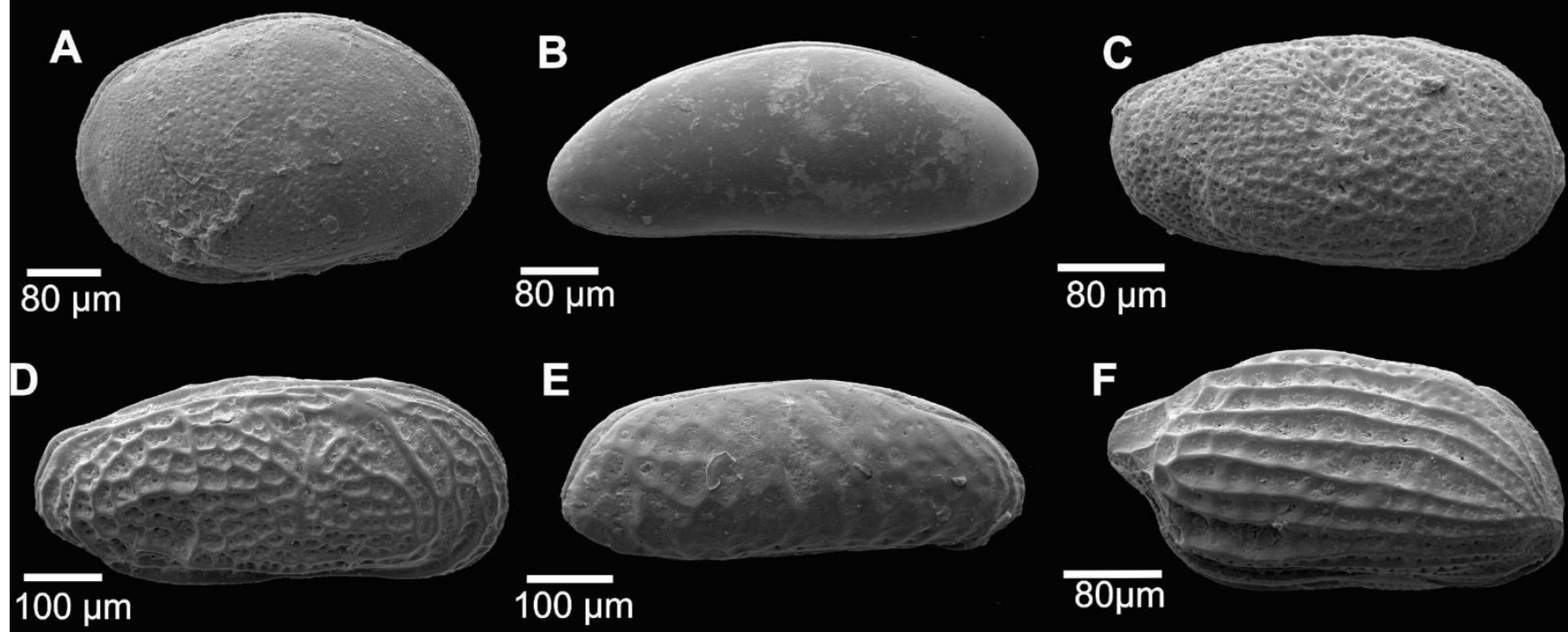

\section{$\overline{80 \mu \mathrm{m}}$}

\section{$80 \mu \mathrm{m}$}
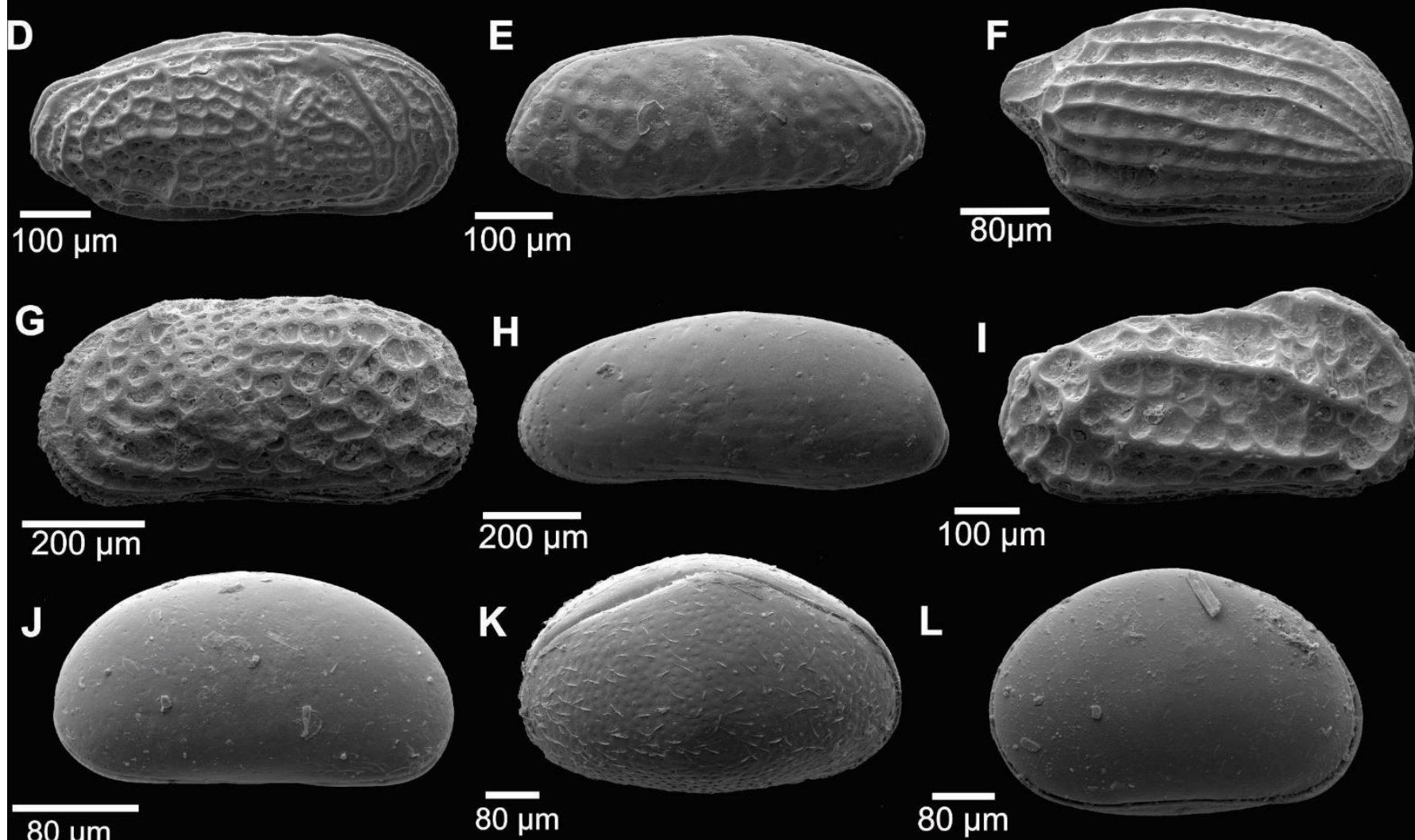

$100 \mu \mathrm{m}$

$80 \mu \mathrm{m}$

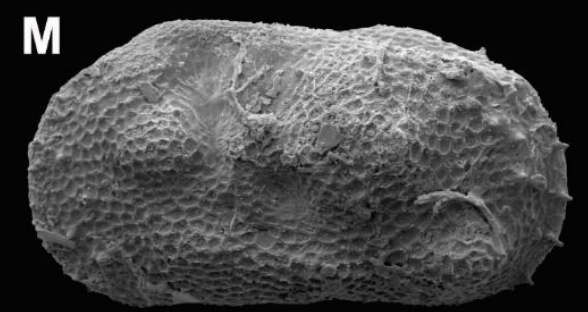

